\title{
Grazing activity increases decomposition of yak dung and litter in an alpine meadow on the Qinghai-Tibet plateau
}

\author{
Chuntao Yang • Yan Zhang • Fujiang Hou $(\mathbb{D} \cdot$ James Peter Millner • Zhaofeng Wang $\cdot$ Shenghua Chang
}

Received: 8 February 2019 / Accepted: 20 August 2019/Published online: 28 August 2019

(C) The Author(s) 2019

\begin{abstract}
Aims This study investigated the influences of herbivore grazing intensity and grazing season on decomposition and nutrient release of dung and litter, which aimed to improve our understandings of grazing affecting nutrient cycling in alpine meadows on the QinghaiTibetan Platean.

Methods A factorial design experiment comprising 3 grazing intensities (non-grazing, moderate grazing, and heavy grazing) and 2 grazing seasons (summer and winter), was applied to quantify the decomposition and chemistry of dung and litter in an alpine pasture using the litterbag technique. Litterbags were retrieved for
\end{abstract}

Chuntao Yang and Yan Zhang should be considered joint first author.

Responsible Editor: Zhanhuan Shang.

Electronic supplementary material The online version of this article (https://doi.org/10.1007/s11104-019-04272-x) contains supplementary material, which is available to authorized users.

C. Yang $\cdot$ Y. Zhang $\cdot$ F. Hou $(\bowtie) \cdot$ Z. Wang $\cdot$ S. Chang State Key Laboratory of Grassland Agro-ecosystems, Key Laboratory of Grassland Livestock Industry Innovation, Ministry of Agriculture, College of Pastoral Agriculture Science and Technology, Lanzhou University, Lanzhou 730020, China e-mail: cyhoufj@1zu.edu.cn

J. P. Millner

Institute of Natural Resources, Massey University, Private Bag

11222, Palmerston North 4410, New Zealand analysis of mass loss and nutrient release with 180 , 360, 540, and 720 days after placement.

Results Grazing activity accelerated the decomposition of dung and litter and increased nutrient release from dung and litter by increasing soil temperature compared with non-grazing pastures, whereas grazing season had no effect on decomposition. The decomposition time was shorter for dung than that for litter.

Conclusions Herbivores grazing benefited dung and litter decomposition and nutrient cycling directly by increasing soil temperature, which is likely to promote soil microbial activity due to low temperatures in alpine meadows, and indirectly through herbage ingestion and dung deposition which increase the organic debris concentration used for microorganisms growth and reproduction. This study provides insights into the mechanisms of grazing regulating nutrient cycling in alpine ecosystems.

Keywords Organic matter - Yak · Grazing activity · Alpine meadow Decomposition

\section{Introduction}

Dung and litter decomposition together play a vital role in nutrient cycling in grazed pastures as well as the energy flow in grassland ecosystems. Organic matter decomposition is dependent on the local climate, including seasonal variations of precipitation and temperature (Gillet 
et al. 2010; Yu et al. 2013), the activity of coprophagous invertebrates and soil microorganisms (Banegas et al. 2015; O'Hea et al. 2010) and its chemical compositions (e.g. contents of C and N) (Song et al. 2017; Sun et al. 2018). In the native ecosystems, organic matter decomposition is synchronized with plant growth and optimal utilization of $\mathrm{C}$ and other nutrients (Gregorich and Janzen 1998), whereas anthropic disturbance may retard or accelerate decomposition as it alters the functional compartments of the ecosystem (Banegas et al. 2015).

Grazing activity is a key component of grassland ecosystems. Herbivores, as a major consumer of herbage, contribute to the nutrient recycling through the return of dung and urine. Grazing affects the litter decomposition processes by altering environmental condition and litter quality (Sun et al. 2018), and the dynamics of nutrient cycling (Semmartin et al. 2004, 2008). Previous publications show that grazing activity of herbivores with different grazing intensities in grazing season may induce considerable changes in the decomposition of dung or litter in grassland ecosystems (Liang et al. 2018; Song et al. 2017; Sun et al. 2018). However, different studies usually generate different results. For example, Shariff et al. (1994) reported that moderate grazing pressure results in a higher litter decomposition compared with non-grazing and heavy grazing. Sun et al. (2018) suggested that litter has a higher rate of decay in a grazed paddock (1.30 to $1.34 \mathrm{~g}^{-1}$ day $^{-1}$ ) compared to that in grazing exclusion (1.04 to $1.20 \mathrm{~g}$ $10 \mathrm{~g}^{-1}$ day $^{-1}$ ), regardless of litter quality. While, Song et al. (2017) found that grazing sheep significantly reduce litter decomposition rate in the local species-rich communities, whereas litter decomposition rate increases in the local species-poor communities at the meadow steppe.

Grazing season or grazing-induced dung deposition may affect litter decomposition and nutrient cycling by altering soil moisture and temperature (Liang et al. 2018; Luo et al. 2010). Indeed, Luo et al. (2010) showed that on the Qinghai-Tibetan Plateau (QTP), warming and grazing may increase litter mass losses by approximately $19 \%$ and $8 \%$, respectively, and increasing $1{ }^{\circ} \mathrm{C}$ will result in an additional $11 \%$ loss of litter mass. Thus, organic matter decomposition on the QTP is more sensitive to increasing temperature than on a pasture at low altitude, due to its extreme environmental conditions of high solar radiation $\left(21 \mathrm{MJ} \mathrm{m}^{-2}\right.$ day $\left.^{-1}\right)$ and high altitude $(\sim 3700 \mathrm{~m})$ (Liu et al. 2012) with low temperature $\left(\sim 1{ }^{\circ} \mathrm{C}\right)$ and partial oxygen pressure (Liu et al. 2018; Sun et al. 2018).

The QTP spans $\sim 2.5$ million $\mathrm{km}^{2}$ making it the largest grassland ecosystem in Eurasia (Cai et al. 2014), supporting open grazing by more than 13.3 million domestic yaks (Yu et al. 2013) with approximately 40 million tons dung directly deposited onto the grassland annually (Liu et al. 2018). Although some yak dung is harvested by herdsmen as source of fuel, pastures under such a huge load would in time be covered by yak dung if the dung did not decompose (Yu et al. 2013). Many publications have investigated the effects of yak dung on soil and pasture (Yu et al. 2013), greenhouse gas emissions (Cai et al. 2013, 2014; Liu et al. 2017), and litter decomposition (Liang et al. 2018) on the QTP. However, minimal information is available regarding the decomposition of dung under different grazing intensities and grazing seasons. Furthermore, our understandings of grazing affecting dung and litter decomposition and nutrient release on QTP are still rudimentary.

A number of studies have noted that nutrient concentration, fractions of stable C compounds (e.g. lignin), and $\mathrm{C} / \mathrm{N}$ ratio are all variables in nature, which will affect microbial activity and consequently alter decomposition rate (Dickinson and Craig 1990; Luo et al. 2010; Murphy et al. 1998; Song et al. 2017). Hence, the decomposition processions of dung and litter are expected to vary due to their different chemical compositions. Meanwhile, grazing herbivores may promote nutrient cycling in alpine meadows through herbage ingestion and excreta deposition, because herbage compaction during the digestion increases the concentration of organic debris used for microorganism growth and reproduction (Dickinson and Craig 1990).

In this study, we investigated the long-term effect of yak grazing activity on mass loss and nutrient release of litter and dung (24 months) with different grazing intensities and grazing seasons, and measured their effects on soil temperature and moisture, which were associated with decomposition processes. The present data were also used to develop a range of prediction equations for the time needed to achieve $75 \%$ mass loss of dung or litter using the predation of mass remaining in litter and dung in relation to decomposition time, and then compared the differences of decomposition time between litter and dung. Based on the information above, we hypothesized that: (1) grazing intensity, grazing season 
or both may accelerate the dung and litter decomposition and thus enhance nutrient release rate, and (2) the decomposition time would be shorter for dung compared with litter. Results derived from the present study may improve our understandings of the mechanisms of grazing regime and grazing season affecting nutrient cycling in alpine meadows, and build upon our existing knowledge relevant to the sustainable utilization of grasslands on the QTP.

\section{Materials and methods}

\section{Study site}

The present study was undertaken at a Lanzhou University Research Station in Maqu County, Gansu Province, China $\left(33^{\circ} 06^{\prime}\right.$ to $34^{\circ} 33^{\prime} \mathrm{N}, 100^{\circ} 46^{\prime}$ to $102^{\circ} 29^{\prime} \mathrm{E}$; elevation, $\left.3700 \mathrm{~m}\right)$. The study site is located in the northeast QTP and has a climate condition of continental cold/humid type. The mean annual temperature during the experimental period is $\sim 2.5{ }^{\circ} \mathrm{C}$; the lowest average monthly temperature, approximately $-10{ }^{\circ} \mathrm{C}$, occurred in January and the highest average monthly temperature, approximately $12{ }^{\circ} \mathrm{C}$, occurred in July. Mean annual precipitation is $678 \mathrm{~mm}$, over $80 \%$ of which fall during the summer (Sun et al. 2018; Fig. S1). Soils are classified as Mat-Cryic Cambisols soil in line with the previous experimental work (Sun et al. 2015). There was no significant difference in soil composition between the experimental paddocks after a long-term grazing history with the same grazing regime. The vegetation found in the study area is characteristic of a typical alpine meadow. The plant communities are dominated by perennial herbaceous species such as Kobresia spp. (e.g. K. graminifolia, K. capillifolia, K. humilis, $K$. Tibetica), Elymus sp. (e.g. E. nutans), Potentilla L. sp. (e.g. P. anserina), Stipa spp. (e.g. S. aliena), and Festuca spp. (e.g. F. ovina) (Yang et al. 2018).

\section{Experimental design}

This study was conducted as a factorial design ( 3 grazing intensities $\times 2$ grazing seasons) from January 2011 to December 2012. In the present study, yaks were selected as grazing herbivores. Four paddocks (approximately 1.5 ha each paddock; Fig. 1) close to the experimental station were established and randomly divided into two groups with different grazing seasons: summer grazing paddocks - yaks grazed on two paddocks from July to September, and winter grazing paddocks - yaks grazed on other two paddocks from October to December. Each paddock was divided into three blocks (approximately 0.5 ha per block) as replicates and were grazed with yaks at moderate intensity (3.4 yaks ha ${ }^{-1}$, Moderate) or heavy intensity (6.8 yaks ha ${ }^{-1}$, Heavy) based on the utilization rate of grazing animals (Dong et al. 2003, 2004) during the grazing periods. Animals grazed daily from 0800 to $1730 \mathrm{~h}$ during daytime and were housed in shelters overnight. During the January to June period each year, yaks were fed with hay in shelters. A $2 \times 2 \mathrm{~m}$ enclosure plot was randomly established and fenced at the beginning of the study in each block (12 plots; two grazing seasons $\times$ two grazing intensities $\times$ three replicated blocks) to serve as the control (non-grazing).

\section{Litter and dung decomposition}

To obtain representative samples, litter and fresh yak dung were collected from the three neighboring paddocks prior to the start of experiment in January 2011. The collected plant litter of dominant species $(42 \%$ (proportion of biomass) Kobresia spp., 19\% E. nutans, $6 \%$ S. aliena, $11 \%$ F. ovina, and $5 \%$ P. anserina) or fresh yak dung was evenly mixed and a single sample was taken and dried at $60{ }^{\circ} \mathrm{C}$ for $48 \mathrm{~h}$ in a forced-air drying oven. The dried sample was then divided into two subsamples and stored in sealed plastic bags. One of the subsamples was ground to measure the initial chemical composition in litter or dung and the other used for the decomposition study using the litterbag method described by Cornelissen (1996).

The dried litter was cut to approximately $5 \mathrm{~cm}$ length and a total of $20 \mathrm{~g}$ litter was packed into a litterbag $(20 \times$ $20 \mathrm{~cm}$ with nylon net of 35-um mesh size), to prevent any loss of material while no inhibiting decomposition (Cornelissen et al. 1999). Similarly $20 \mathrm{~g}$ of dried dung was placed into nylon litterbags. Replicate litterbags with litter or dung were placed above the soil surface at five locations in each grazing block or each enclosure plot on January 10, 2011. All litterbags were fastened to the ground with four steel stakes to prevent displacement by yaks or small animals (Sun et al. 2018). There were a total of 120 litterbags containing litter or dung used in this study. In each paddock, 30 litterbags (3 blocks $\times 5$ replicates +3 plots $\times 5$ replicates) with either litter or dung were incubated $20 \mathrm{~cm}$ apart from each 
Fig. 1 Location of sampling and partition of blocks in the present study. Summer grazing paddocks, paddocks $1(\mathrm{P} 1)$ and $2(\mathrm{P} 2)$ were grazed from July to September; winter grazing paddocks, paddocks 3 (P3) and 4 (P4) were grazed from October to December

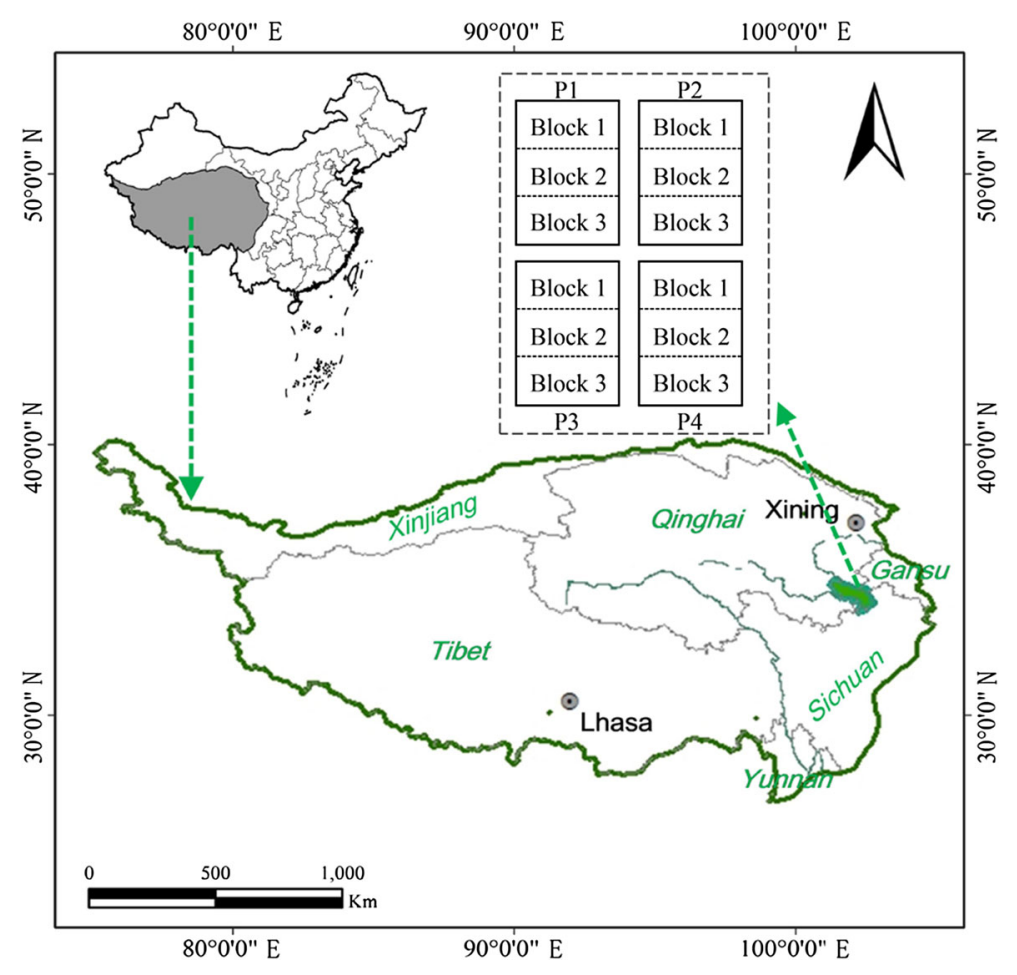

other to reduce the mutual interference. Six litterbags with litter or dung respectively were respectively retrieved from each paddock at $180,360,540$, or $720 \mathrm{~d}$ after incubation, then cleaned to eliminate any effect of soil contamination and dried at $60^{\circ} \mathrm{C}$ for $48 \mathrm{~h}$. The oven dried samples were weighed to determine the loss of mass of both dung and litter, and then ground and stored in sealed plastic bags for analysis of chemical composition.

The contents of organic $\mathrm{C}$, total $\mathrm{N}$, total $\mathrm{P}$, total $\mathrm{K}$, or total $\mathrm{Mg}$ in initial and incubation samples were determined. The total organic $\mathrm{C}$ was analyzed using the wet combustion method in the presence of $\mathrm{K}_{2} \mathrm{Cr}_{2} \mathrm{O}_{7}$ and concentrated $\mathrm{H}_{2} \mathrm{SO}_{4}$ at $170-180{ }^{\circ} \mathrm{C}$ (Liu et al. 2017). The total $\mathrm{N}$ was measured using a semi-micro Kjeldahl digestion procedure (Greenfield and Southgate 1992). The total $\mathrm{P}$ was measured by colorimetry after digesting samples in perchloric acid (ISSCAS 1978), and total K and $\mathrm{Mg}$ were determined by flame photometry (Eaten et al. 1992).

To evaluate the effects of grazing regime on soil characteristics, five sites in each plot or block were randomly selected and the surface layer temperature (at $5 \mathrm{~cm}$ depth) and moisture content $(0-10 \mathrm{~cm})$ were measured using a portable thermometer (DSE; TP 101) and a bucket auger (10 $\mathrm{cm}$ in diameter), respectively.
Soil temperature was continuously measured at $1000 \mathrm{~h}$ and $1400 \mathrm{~h}$ and soil moisture content was determined at $1500 \mathrm{~h}$ on the day before end of grazing in September and December 2012, respectively. The mean value of measurements derived from each plot or block was taken to analysis the differences between the treatments.

\section{Statistical analysis}

A Shapiro-Wilk test was used to test the normality of data before mean comparison. The difference in the initial chemical composition of dung and litter was compared using an independent $t$-test (Table 1). Data on residual mass (Table 2 and Fig. 2), element contents (Figs. 3 and 4) and element decomposition rate ( $k$, see below; Table 3) of dung or litter, and soil temperature and moisture (Fig. S2) affected by grazing intensity and grazing season were analyzed using a two-way analysis of variance (ANOVA) with a Tukey test for multiple comparisons. Significant level was set as $P<0.05$.

Exponential function was used to model the relationship between amount remaining proportion $\left(X / X_{0}\right)$ and incubation time $(t)$ (Fig. 5) according to Olson (1963): $X / X_{0}=e^{-k t}$, where $X_{0}$ was the original mass, $X$ the amount remaining at time $t$ (days), and $k$ the decay rate coefficient. The time needed to achieve $75 \%$ mass loss 
of dung or litter, was estimated according to Weeda (1967). All analyses were carried out using SAS 9.3 (SAS Institute Inc., Cary, NC, USA). All figures were produced by Excel 2007 software.

\section{Results}

\section{Chemical compositions}

The difference in chemical composition of dung and litter is shown in Table 1 . The total $\mathrm{N}, \mathrm{P}, \mathrm{K}$, and $\mathrm{Mg}$ contents in dung were significantly greater than that in litter $(P<0.0001)$. There was no difference in total $\mathrm{C}$ content between dung and litter $(P=0.2752)$ and as a consequence, the $\mathrm{C} / \mathrm{N}$ ratio in dung was significantly lower compared with litter $(P<0.0001)$.

\section{Mass loss}

Grazing intensity significantly influenced the mass loss of dung, with significantly higher dung mass remaining in Control paddocks than that in Moderate (i.e. SummerModerate and Winter-Moderate) and Heavy (i.e. Summer-Heavy and Winter-Heavy) grazing paddocks after incubated for $540(P=0.0001)$ and 720 days $(P<0.0001)$ (Table 2 and Fig. 2a). Similarly litter mass remaining was the highest in the Control, intermediate in the Moderate and Winter-Heavy grazing paddocks, and lowest in the Summer-Heavy grazing paddocks after incubated for $360 \sim 720$ days $(P=0.0013$; Fig. $2 b)$. However, grazing season did not significantly influence mass remaining in dung $(P=0.0806)$ and litter $(P=0.0679)$.

Table 1 Mean ( \pm SE) chemical compositions in initial yak dung and litter used in the present study $(n=15)$

\begin{tabular}{llll}
\hline Item & Dung & Litter & $P$ value \\
\hline Total C $\left(\mathrm{g} \mathrm{kg}^{-1}\right)$ & $434.49 \pm 4.53 \mathrm{a}$ & $428.13 \pm 3.47 \mathrm{a}$ & 0.2752 \\
Total N $\left(\mathrm{g} \mathrm{kg}^{-1}\right)$ & $18.42 \pm 0.20 \mathrm{a}$ & $11.62 \pm 0.31 \mathrm{~b}$ & $<0.0001$ \\
$\mathrm{C} / \mathrm{N}$ & $23.63 \pm 0.36 \mathrm{~b}$ & $36.84 \pm 1.15 \mathrm{a}$ & $<0.0001$ \\
$\mathrm{~K}\left(\mathrm{~g} \mathrm{~kg}^{-1}\right)$ & $4.30 \pm 0.05 \mathrm{a}$ & $1.64 \pm 001 \mathrm{~b}$ & $<0.0001$ \\
$\mathrm{P}\left(\mathrm{g} \mathrm{kg}^{-1}\right)$ & $3.80 \pm 0.04 \mathrm{a}$ & $1.43 \pm 0.01 \mathrm{~b}$ & $<0.0001$ \\
$\mathrm{Mg}\left(\mathrm{mg} \mathrm{kg}^{-1}\right)$ & $3.11 \pm 0.03 \mathrm{a}$ & $0.87 \pm 0.01 \mathrm{~b}$ & $<0.0001$ \\
\hline
\end{tabular}

Means within a row with different letters significantly differ $(P<0.05)$
Chemical composition decomposition

Compared with Control, dung and litter incubated in Moderate grazing paddocks had significantly lower C, $\mathrm{N}, \mathrm{P}$ and $\mathrm{K}$ contents after incubated for $360 \sim 720$ days $(P=0.0282)$ (Figs. 3 and 4$)$. The estimated decomposition rates $(k)$ of chemical compositions in litter or dung were shown in Table 3. The release rates of C, N, P, and $\mathrm{K}$ were usually significantly greater in the Moderate and Heavy grazing paddocks than in the Control paddocks, with the exception of $\mathrm{Mg}$ release rate of litter. Summer grazing increased the $\mathrm{N}$ release rate in dung in comparison with winter grazing. There was no interaction in element decay rate of dung or litter between grazing intensity and grazing season.

Prediction of decomposition time

As shown in Fig. 5 (also see Table 4), both dung and litter decomposed faster in the Summer-Heavy grazing paddocks than in the Control paddocks. Moderate and Heavy grazing reduced the decomposition time by $36 \%$ to $45 \%$ for dung (Fig. $5 \mathrm{a}$ ) and by $25 \%$ to $35 \%$ for litter (Fig. 5b) compared with the Control. The time required to achieve $75 \%$ mass loss of litter was longer (758.2 to 1174.1 days) than that for dung (563.8 to 1027.1 days), irrespective of grazing intensity and grazing season.

\section{Discussion}

Mass decomposition

The time required to complete decomposition of organic detritus on pastures varies from a few weeks in tropical seagrass meadows (Vonk et al. 2008) to several years in alpine meadows (Liang et al. 2018; Sun et al. 2018; Yu et al. 2013). Under the given climatic conditions, the ecological processes of dung and litter decomposition are regulated by incubation microenvironment (e.g. grazing activity and soil property) and their chemical compositions. In agreement with previous findings (Sun et al. 2018), yak grazing increased the mass loss and shortened the decomposition time for both dung and litter on the QTP. This suggests that herbivore grazing may play a vital role in dung and litter decomposition.

Previous studies have revealed how grazing herbivores improve organic matter decomposition on the 
Table 2 Effects of grazing intensity and grazing season on mass remaining in dung and litter $(n=3)$ after different decomposition times (days)

\begin{tabular}{|c|c|c|c|c|c|c|c|}
\hline \multirow[t]{2}{*}{ Item } & \multirow[t]{2}{*}{ Time } & \multicolumn{2}{|c|}{ Grazing intensity } & \multicolumn{2}{|c|}{ Grazing season } & \multicolumn{2}{|c|}{ Grazing intensity $\times$ Grazing season } \\
\hline & & $F$ & $P$ value & $F$ & $P$ value & $F$ & $P$ value \\
\hline \multirow[t]{4}{*}{ Dung } & 180 & 1.55 & 0.2510 & 0.00 & 0.9931 & 0.31 & 0.7420 \\
\hline & 360 & 4.65 & 0.0617 & 1.75 & 0.2112 & 2.87 & 0.0963 \\
\hline & 540 & 60.31 & 0.0001 & 4.04 & 0.0806 & 5.84 & 0.0166 \\
\hline & 720 & 48.79 & $<0.0001$ & 0.32 & 0.5802 & 2.10 & 0.1652 \\
\hline \multirow[t]{4}{*}{ Litter } & 180 & 1.45 & 0.2743 & 0.34 & 0.5721 & 0.93 & 0.4218 \\
\hline & 360 & 13.03 & 0.0013 & 2.50 & 0.1778 & 1.10 & 0.3640 \\
\hline & 540 & 38.41 & $<0.0001$ & 11.93 & 0.0853 & 5.20 & 0.0237 \\
\hline & 720 & 63.82 & $<0.0001$ & 4.04 & 0.0679 & 2.32 & 0.1414 \\
\hline
\end{tabular}

pastures by influencing the incubation microclimate (e.g. soil temperature and soil moisture), chemical compositions (e.g. contents of $\mathrm{C}$ and $\mathrm{N}$ ) of litter, and soil organisms (Aerts 2006; Luo et al. 2010; Song et al. 2017; Sun et al. 2018). In the present study, the chemical quality of the incubation materials (i.e. dung or litter) was consistent by collecting from same pastures, whereas the surface soil property was significantly different between different grazing intensities, with higher soil temperature and lower soil moisture content in grazing pastures than in the enclosures during the grazing seasons (Fig. S2). Berg et al. (1993) analyzed the relationship between incubation climate and litter quality on litter mass loss and suggested that temperature and moisture in combination were the most important climatic control factors on litter decomposition rate. However, in the present study, mass decomposition rates in dung and litter were significantly positively correlated with soil temperature (Table S1), irrespective of summer and winter grazing. In contrast, a significant negative relationship between decomposition rate and soil moisture was recorded in summer grazing. Davidson and Janssens (2006) and Luo et al. (2010) suggested that the differences in organic matter decomposition greatly depend on soil temperature. In the present study, an increasing soil temperature is likely to promote soil
Fig. 2 Effects of grazing intensity (Control, non-grazing; Moderate, 3.4 yaks ha $^{-1}$; Heavy, 6.8 yaks ha $^{-1}$ ) and grazing season (summer and winter) on mean $( \pm \mathrm{SE})$ mass remaining in dung and litter $(n=3)$ after different decomposition times. Means within a row with different letters significantly differ $(P<0.05)$

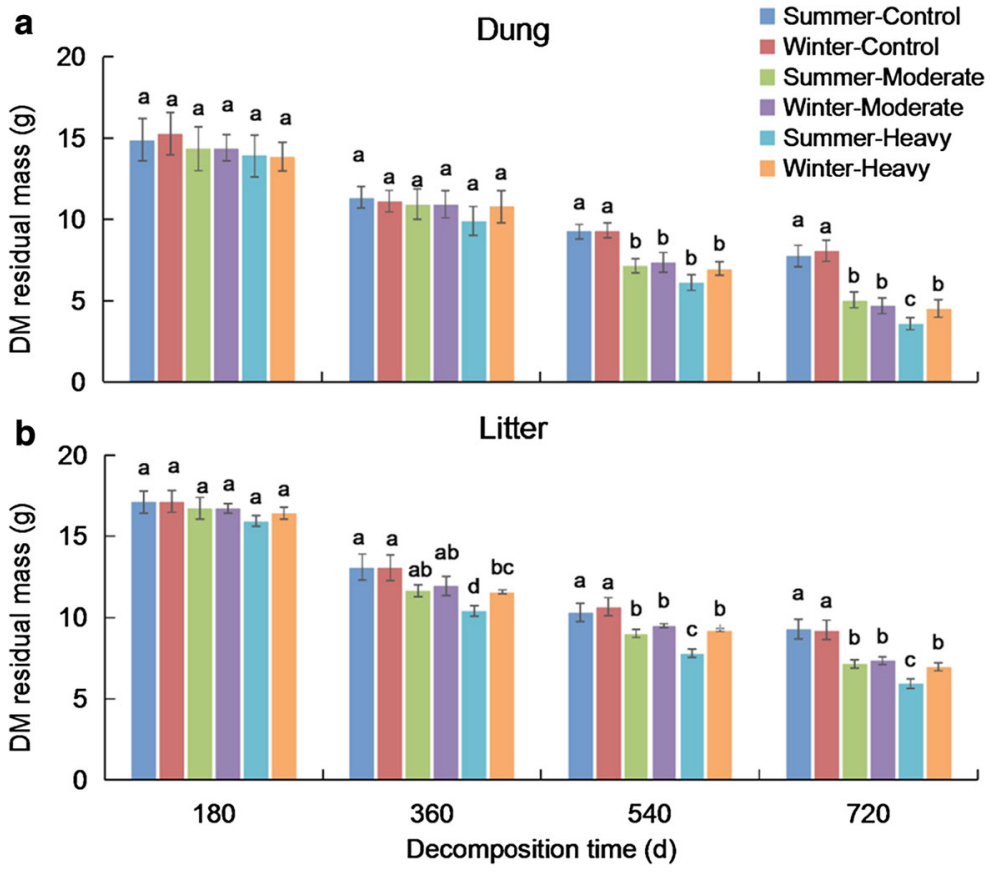



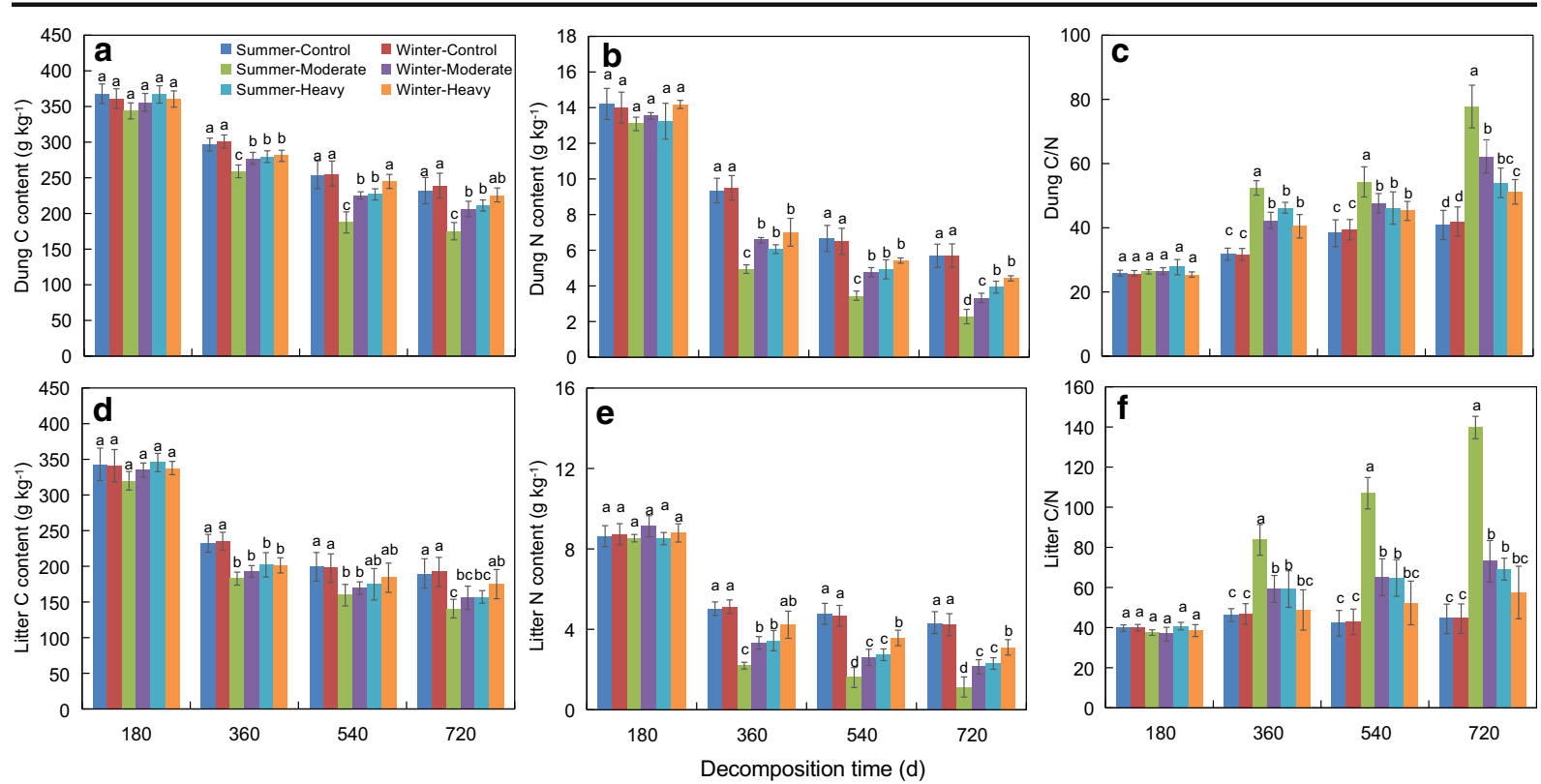

Fig. 3 Effects of grazing intensity (Control, non-grazing; Moderate, 3.4 yaks ha ${ }^{-1}$; Heavy, 6.8 yaks ha $^{-1}$ ) and grazing season (summer and winter) on mean $( \pm \mathrm{SE})$ total contents $\left(\mathrm{g} \mathrm{kg}^{-1}\right.$ initial

microbial activity due to the low temperatures in the alpine meadow at high altitudes (Fig. S1). Furthermore, as there is generally sufficient soil moisture in the alpine meadows to support microbial activity, it only became mass) of organic carbon $(\mathrm{C})$ and nitrogen $(\mathrm{N})$ and $\mathrm{C} / \mathrm{N}$ in dung and litter $(n=3)$ after different decomposition times. Means within a row with different letters significantly differ $(P<0.05)$

limiting to the overall decomposition rate during summer (Luo et al. 2010).

Although the effects of grazing intensity on soil property were not measured in the present study, long-
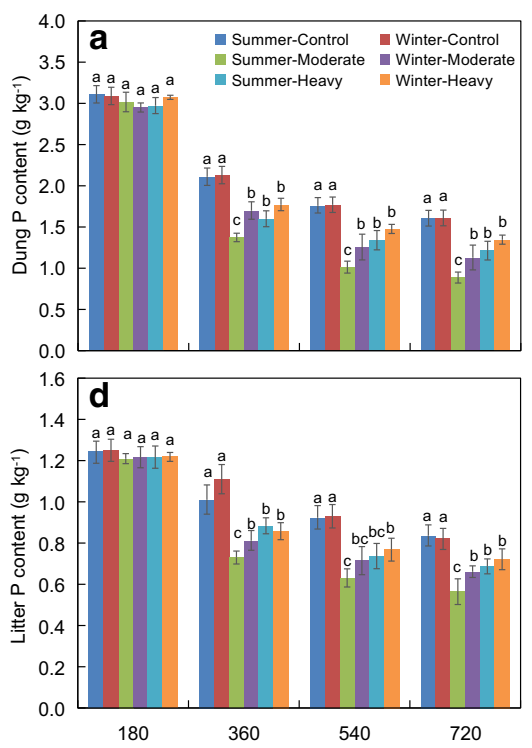
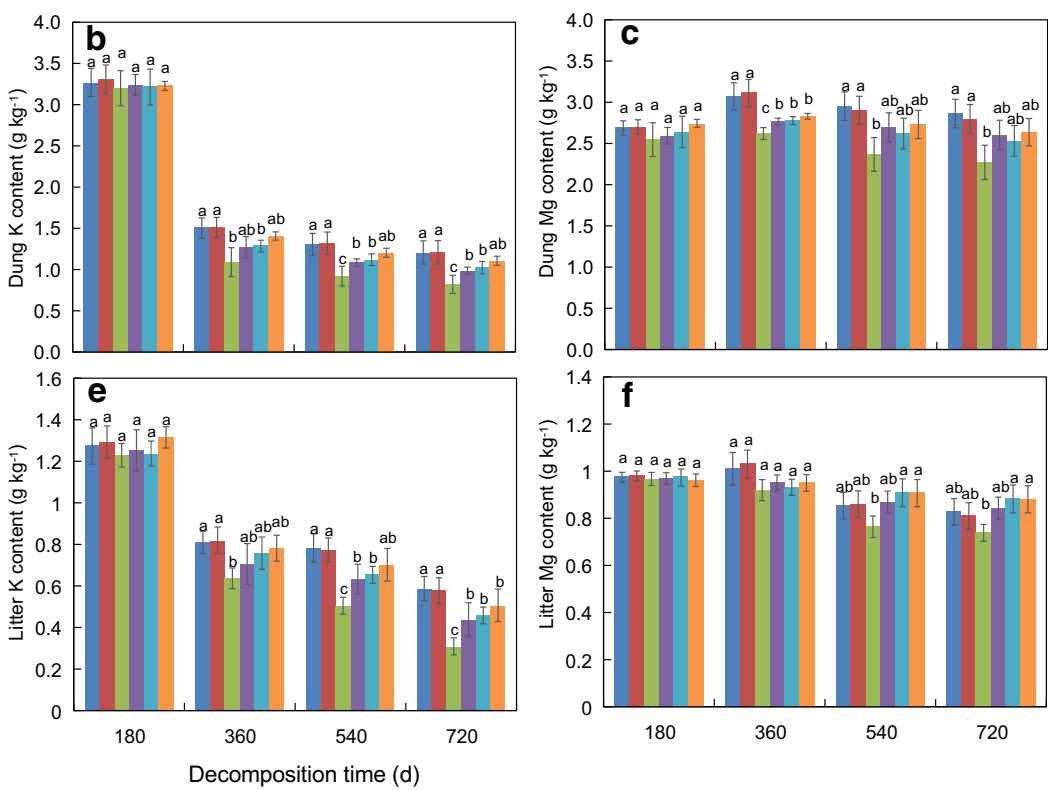

Fig. 4 Effects of grazing intensity (Control, non-grazing; Moderate, 3.4 yaks ha $^{-1}$; Heavy, 6.8 yaks ha $^{-1}$ ) and grazing season (summer and winter) on mean $( \pm \mathrm{SE})$ total content of phosphorus (P, $\mathrm{g} \mathrm{kg}^{-1}$ initial mass), potassium ( $\mathrm{K}, \mathrm{g} \mathrm{kg}^{-1}$ initial mass), or magnesium ( $\mathrm{Mg}, \mathrm{mg} \mathrm{kg}^{-1}$ initial mass) in dung and litter $(n=3)$ after different decomposition times. Means within a row with different letters significantly differ $(P<0.05)$ 
Table 3 Effects of grazing intensity (Control, non-grazing; Moderate, 3.4 yaks ha ${ }^{-1}$; Heavy, 6.8 yaks ha $^{-1}$ ) and grazing season (summer and winter) on element decomposition rate $(k)$ in dung and litter $(n=3)$ over the study

\begin{tabular}{|c|c|c|c|c|c|c|c|c|}
\hline \multirow[t]{2}{*}{ Item } & \multicolumn{3}{|c|}{ Grazing intensity } & \multicolumn{2}{|c|}{ Grazing season } & \multicolumn{3}{|l|}{$P$ value } \\
\hline & Control & Moderate & Heavy & Summer & Winter & Grazing intensity & Grazing season & Grazing intensity $\times$ Grazing season \\
\hline \multicolumn{9}{|c|}{ Dung $(\%)$} \\
\hline $\mathrm{C}$ & $0.76 b$ & $0.99 \mathrm{a}$ & $0.84 \mathrm{ab}$ & $0.95 \mathrm{a}$ & $0.88 \mathrm{a}$ & 0.0213 & 0.2843 & 0.6367 \\
\hline $\mathrm{N}$ & $1.02 \mathrm{~b}$ & $1.54 \mathrm{a}$ & $1.39 \mathrm{a}$ & $1.38 \mathrm{a}$ & $1.25 \mathrm{~b}$ & 0.0011 & 0.0051 & 0.0869 \\
\hline $\mathrm{P}$ & $0.87 \mathrm{~b}$ & $1.26 \mathrm{a}$ & $1.18 \mathrm{a}$ & $1.15 \mathrm{a}$ & $1.05 \mathrm{a}$ & $<0.0001$ & 0.0709 & 0.4021 \\
\hline $\mathrm{K}$ & $1.07 \mathrm{~b}$ & $1.37 \mathrm{a}$ & $1.24 \mathrm{ab}$ & $1.30 \mathrm{a}$ & $1.22 \mathrm{a}$ & 0.0113 & 0.1088 & 0.4370 \\
\hline $\mathrm{Mg}$ & $0.47 \mathrm{~b}$ & $0.71 \mathrm{a}$ & $0.75 \mathrm{a}$ & $0.67 \mathrm{a}$ & $0.61 \mathrm{a}$ & $<0.0001$ & 0.1102 & 0.3931 \\
\hline \multicolumn{9}{|c|}{ Litter (\%) } \\
\hline $\mathrm{C}$ & $0.75 b$ & $0.94 \mathrm{a}$ & $0.97 \mathrm{a}$ & $0.92 \mathrm{a}$ & $0.84 a$ & 0.0012 & 0.1762 & 0.5660 \\
\hline $\mathrm{N}$ & $0.83 \mathrm{~b}$ & $1.46 \mathrm{a}$ & $1.20 \mathrm{a}$ & $1.26 \mathrm{a}$ & $1.06 \mathrm{a}$ & $<0.0001$ & 0.0736 & 0.4119 \\
\hline $\mathrm{P}$ & $0.63 b$ & $0.85 \mathrm{a}$ & $0.81 \mathrm{a}$ & $0.80 \mathrm{a}$ & $0.73 \mathrm{a}$ & 0.0010 & 0.3298 & 0.7057 \\
\hline K & $0.87 b$ & $1.18 \mathrm{a}$ & $1.08 \mathrm{ab}$ & $1.09 \mathrm{a}$ & $0.99 \mathrm{a}$ & 0.0359 & 0.1072 & 0.4708 \\
\hline $\mathrm{Mg}$ & $0.44 \mathrm{a}$ & $0.58 \mathrm{a}$ & $0.61 \mathrm{a}$ & $0.57 \mathrm{a}$ & $0.51 \mathrm{a}$ & 0.1033 & 0.2360 & 0.2511 \\
\hline
\end{tabular}

For each category (i.e. grazing intensity or grazing season), means within a row with different letters significantly differ $(P<0.05)$

term grazing activity may promote an increase in soil total $\mathrm{N}$, organic matter and organic $\mathrm{C}$ due to dung and

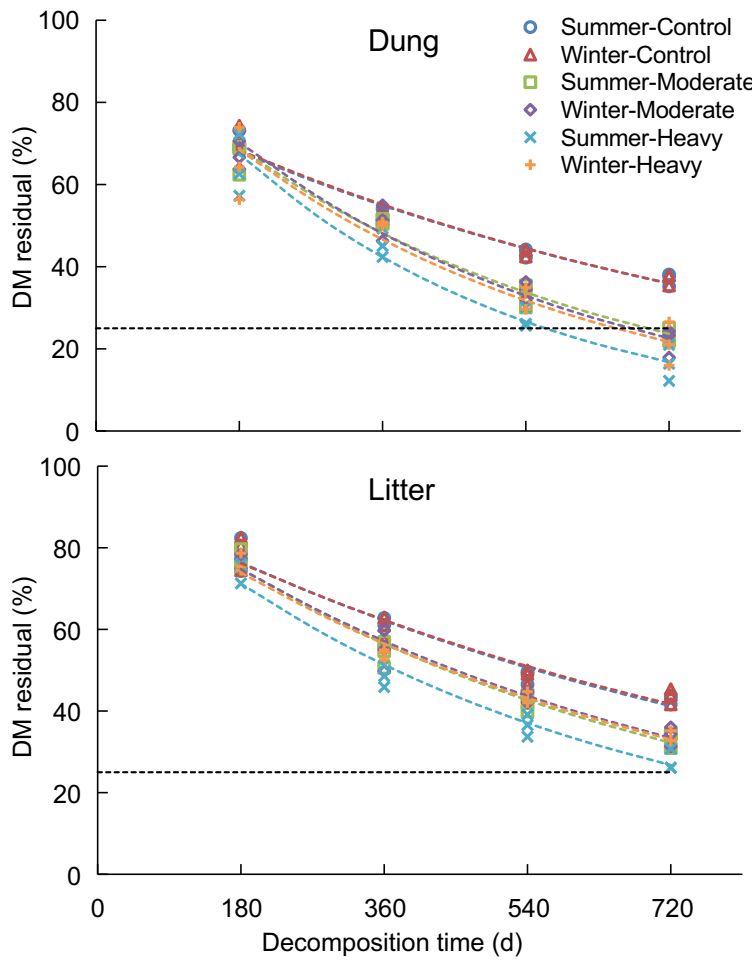

Fig. 5 Relationship between decomposition time and mass remaining in dung or litter $(n=3)$ for different grazing intensities (Control, non-grazing; Moderate, 3.4 yaks ha $^{-1}$; Heavy, 6.8 yaks $\mathrm{ha}^{-1}$ ) and grazing seasons (summer and winter) urine deposition (Liang et al. 2018). This may in turn accelerate decomposer growth and activity (Manzoni et al. 2008), which consequently influences the dung and litter decomposition in grazing pastures. However, in the present study Moderate grazing did not optimize nutrient cycling and improve dung or litter decomposition compared with Heavy grazing. This result disagrees with the findings of Shariff et al. (1994), who showed that decomposition rate is consistently higher in moderate grazing pastures than in non-grazing or heavy grazing ones. Additionally, the effects of trampling by large herbivores on shredding of physical structure in dung or litter cannot be ignored (Sun et al. 2015), as this may also accelerate mass loss in dung or litter.

It is worthy of note that in the present study the decomposition time required to achieve $75 \%$ mass loss in dung ranged from 563.8 to 1027.1 days, which was approximately 6-fold (from 95 to 174 days) and 13-fold longer (from 45 to 80 days) than that reported in New Zealand (Weeda 1967) and England (Dickinson et al. 1981), respectively. The contradictory results between the present study and that of Weeda (1967) and Dickinson et al. (1981) may be attributed to the fact that the annual temperature on the QTP $\left(2.5^{\circ} \mathrm{C}\right)$ is low than that in New Zealand $\left(11.1^{\circ} \mathrm{C}\right)$ and in England $\left(9.2^{\circ} \mathrm{C}\right)$, causing a decrease of microbial and enzymatic activity in soil and dung. Yu et al. (2013) showed that yak dung takes 3 to 5 years or even longer to complete decomposition in enclosures on the QTP. Therefore, organic 
Table 4 Predation of mass remaining $(y, \%)$ in dung or litter $(n=3)$ in relation to decomposition time ( $x$, days) at different grazing intensities (Control, non-grazing; Moderate, 3.4 yaks ha $^{-1}$; Heavy, 6.8 yaks ha $^{-1}$ ) and grazing seasons (summer and winter)

\begin{tabular}{|c|c|c|c|}
\hline Item & Equation & $\mathrm{R}^{2}$ & Decomposition time (days) for $75 \%$ mass loss \\
\hline \multicolumn{4}{|l|}{ Dung } \\
\hline Summer-Control & $y=84.003 \mathrm{e}^{-0.00118 x}$ & 0.9681 & 1027.1 \\
\hline Winter Control & $y=84.693 \mathrm{e}^{-0.00119 x}$ & 0.9680 & 1025.3 \\
\hline Summer-Moderate & $y=98.102 \mathrm{e}^{-0.00198 x}$ & 0.9772 & 690.5 \\
\hline Winter-Moderate & $y=102.55 \mathrm{e}^{-0.00210 x}$ & 0.9522 & 672.1 \\
\hline Summer-Heavy & $y=107.07 \mathrm{e}^{-0.00258 x}$ & 0.9329 & 563.8 \\
\hline Winter-Heavy & $y=100.42 \mathrm{e}^{-0.00213 x}$ & 0.9107 & 652.8 \\
\hline \multicolumn{4}{|l|}{ Litter } \\
\hline Summer-Control & $y=93.766 \mathrm{e}^{-0.00114 x}$ & 0.9540 & 1159.6 \\
\hline Winter Control & $y=93.115 \mathrm{e}^{-0.00112 x}$ & 0.9415 & 1174.1 \\
\hline Summer-Moderate & $y=99.145 \mathrm{e}^{-0.00156 x}$ & 0.9722 & 883.1 \\
\hline Winter-Moderate & $y=97.763 \mathrm{e}^{-0.00149 x}$ & 0.9653 & 915.2 \\
\hline Summer-Heavy & $y=98.618 \mathrm{e}^{-0.00181 x}$ & 0.9652 & 758.2 \\
\hline Winter-Heavy & $y=98.612 \mathrm{e}^{-0.00155 x}$ & 0.9766 & 885.4 \\
\hline
\end{tabular}

matter degradation and nutrient return to the soil occurs at a much slower rate on the QTP than elsewhere due to the extreme environmental conditions at high altitudes, but grazing activity may contribute to shorten the dung decomposition time. However, compared with grazing intensity, grazing season had less effect on dung or litter decomposition on the QTP, although summer grazing shortened the decomposition time of litter compared with winter grazing (Fig. 5).

The sensitivity of dung and litter decomposition to grazing activity will influence the rate of nutrient cycling within the ecosystem on the QTP (Davidson and Janssens 2006; Luo et al. 2010). Dung mass is usually greater than litter biomass depending on grazing intensity in a grazing ecosystem (Luo et al. 2010), while, whether dung could decompose faster than litter at high altitudes is still not clear. In the present study, the decomposition time required for $75 \%$ mass loss of dung was shortened by $13 \%$ (non-grazing pasture) to $26 \%$ (grazing pasture) compared with that recorded for litter, irrespective of summer grazing and winter grazing. The results indicate that dung decomposition is faster than litter and also imply that dung decomposition could more sensitive to the change of temperature compared with litter decomposition (shorten decomposition time $26 \%$ in grazing pasture vs $13 \%$ in enclosure), because of increasing soil temperature caused by grazing activity (Fig. S2). Luo et al. (2010) showed that when the temperature increases $1{ }^{\circ} \mathrm{C}$, annual dung mass loss increased by approximately $18 \%$ which was three times higher than that of litter on the Tibetan plateau.

Evidence indicates that organic matter quality (e.g. nutrient concentration, fractions of stable $\mathrm{C}$ compounds, and $\mathrm{C} / \mathrm{N}$ ratio) plays a vital role in microbial activity and a higher $\mathrm{N}$ content could increase its decomposition rate (Luo et al. 2010; Song et al. 2017; Sun et al. 2018). The results of the present study support this conclusion, namely that greater $\mathrm{N}$ content and lower $\mathrm{C} / \mathrm{N}$ ration in dung increased the mass loss. Additionally, the difference in mass loss between dung and litter may be due to the different moisture content of dung and litter. It is reported that precipitation event is likely to keep the relatively bulky dung samples moist for a longer time which benefits microbiological degradation, and conversely, the thin litter samples may dry quickly (Liang et al. 2018; Luo et al. 2010). Therefore, large amount of dung deposited on the grasslands by grazing yaks in grazing system would accelerate nutrient return to soil through rapid decomposition.

\section{Nutrient release}

Nutrient release from plant residues into soil involves complex processes subject to biological degradation (Berg and McClaugherty 2008; Sun et al. 2018). During these processes, the decomposers transfer organic $\mathrm{C}$ and $\mathrm{N}$ into inorganic matter (e.g. $\mathrm{CO}_{2}$ and $\mathrm{NO}_{3}{ }^{-}$) via respiration, immobilization or mineralization, then those inorganic matter will be absorbed and utilized by 
plants (Aarons et al. 2004; Cai et al. 2013; Chen et al. 2011) and whilst provide energy to the decomposers (Manzoni et al. 2008). Similar to the results of mass losses in dung and litter, grazing activity significantly increased the organic $\mathrm{C}$ and nutrient (i.e. $\mathrm{N}, \mathrm{P}, \mathrm{K}$, and $\mathrm{Mg}$ in the present study) decay rates of dung and litter than those from non-grazing treatment. Because grazing activity increased soil temperature (Fig. S2), which will consequently alter the decomposition processes of microorganisms (Banegas et al. 2015; Luo et al. 2010).

Meanwhile, grazing herbivores may have a major effect on the movement of nutrients and the fertility of pasture soils as $60 \%$ to $90 \%$ of ingested nutrients are returned to the soil in the form of dung and urine (Haynes and Williams 1993; Tracy and Zhang 2008). Indeed, Semmartin et al. (2008) found that nutrient release is faster in grazed sites than in non-grazed ones, linking this to the greater availability of $\mathrm{N}$ in the soil. Nutrients can be recycled back to the pastures through grazing livestock excreta which represents an important source for decomposing microorganisms (Banegas et al. 2015) and induces nutrient release rate (Table 3). Berg and McClaugherty (2008) and Manzoni et al. (2008) suggested that $\mathrm{N}$ release in mineral forms (e.g. ammonium and nitrate) from a given organic residue only occurs after $\mathrm{N}$ content reaches a critical value. This is due to the property of higher $\mathrm{N} / \mathrm{C}$ ratio found in decomposers, which results in a more-efficient $\mathrm{C}$ utilization and a less-efficient $\mathrm{N}$ use for the substrate (Bernal et al. 2009; Unuofin and Mnkeni 2014). Results derived from this study show the $\mathrm{C} / \mathrm{N}$ ratio increased in dung (Fig. 3c) and litter (Fig. 3f) over the incubation time. This unexpected finding may be a consequence of the low oxygen pressure on the QTP (Cai et al. 2013; Lu et al. 2015), which increased denitrification of anaerobic bacteria, and inhibited respiration of aerobic bacteria in the soil. Cai et al. (2014) also showed that a large emission rate of $\mathrm{N}_{2} \mathrm{O}$ and a small release rate of $\mathrm{CO}_{2}$ occurred in the yak dung pats on the QTP, owing to the denitrification stimulated by the large amount of soil $\mathrm{NO}_{3}{ }^{-}$and the decreased oxygen availability at a high altitude.

Consistent with mass loss, grazing season and the interaction between grazing intensity and grazing season, had little influence on $\mathrm{C}$ cycling and nutrient release (Table 3). However, summer grazing increased the $\mathrm{N}$ release rate in dung (Table 3). This can be explained by the large temperature differences recorded between day and night during the summer and the trampling by the herbivores which may accelerate the physical fragmentation of dung (Banegas et al. 2015; Song et al. 2017), hence encouraging $\mathrm{N}$ leaching.

\section{Conclusions}

Findings from this study suggest that grazing activity can improve the mass loss of and nutrient release in dung and litter. Grazing season had little influence on dung and litter decomposition on the QTP. Additionally, the decomposition time was shorter for dung than that for litter, irrespective of the effects of grazing intensity and grazing season. The results indicate that grazing herbivores could improve organic matter decomposition and nutrient cycling of grassland ecosystems by directly inducing a change in incubation environment and indirectly increasing herbage ingestion and dung excreta deposition in alpine meadows. Knowledge generated from this study would help us understand insights into mechanisms of grazing regulating nutrient cycling in alpine meadows and develop strategies for the sustainable utilization of grasslands on the QTP.

Acknowledgements This work was supported by the Project of the Second Tibetan Plateau Scientific Expedition (2019QZKK0302), Strategic Priority Research Program of Chinese Academy of Sciences (XDA2010010203), National Natural Science Foundation of China (31672472), Program for Changjiang Scholars and Innovative Research Team in University (IRT17R50). The authors thank Yi Sun and Yang Liu for their assistance of sample collection, four anonymous reviewers for their constructive comments and suggestions which have significantly improved the paper. We also grateful to Dr. Samuel Hawe for his time spent editing the English of the paper.

\section{Compliance with ethical standards}

Conflict of interest The authors declare that they have no conflict of interest.

Open Access This article is distributed under the terms of the Creative Commons Attribution 4.0 International License (http:// creativecommons.org/licenses/by/4.0/), which permits unrestricted use, distribution, and reproduction in any medium, provided you give appropriate credit to the original author(s) and the source, provide a link to the Creative Commons license, and indicate if changes were made.

\section{References}

Aarons SR, Hosseini HM, Dorling L, Gourley CJP (2004) Dung decomposition in temperate dairy pastures. II. Contribution to plant-available soil phosphorus. Aust J Soil Res 42:115123. https://doi.org/10.1071/SR03009 
Aerts R (2006) The freezer defrosting: global warming and litter decomposition rates in cold biomes. J Ecol 94:713-724. https://doi.org/10.1111/j.1365-2745.2006.01142.x

Banegas N, Albanesi AS, Pedraza RO, Dos Santos DA (2015) Non-linear dynamics of litter decomposition under different grazing management regimes. Plant Soil 393:47-56. https://doi.org/10.1007/s11104-015-2472-y

Berg B, McClaugherty C (2008) Plant litter: decomposition, humus formation and carbon sequestration, 2nd edn. SpringerVerlag, Berlin, Heidelberg, p 341

Berg B, Berg MP, Bottner P, Box E, Breymeyer A, Ca de Anta R, Couteaux M, Escudero A, Gallardo A, Kratz W, Madeira M, Mälkönen E, McClaugherty C, Meentemeyer V, Muñoz F, Piussi P, Remacle J, Vi de Santo A (1993) Litter mass loss rates in pine forests of Europe and eastern United States: some relationships with climate and litter quality. Biogeochemistry 20:127-159. https://doi.org/10.1007 /BF00000785

Bernal MP, Alburquerque JA, Moral R, Vanotti M, Szogi A, Bernal MP, Martinez J (2009) Composting of animal manures and chemical criteria for compost maturity assessment. Bioresour Technol 100:5444-5453. https://doi.org/10.1016/j. biortech.2008.11.027

Cai Y, Wang X, Ding W, Tian L, Zhao H, Lu X (2013) Potential short-term effects of yak and Tibetan sheep dung on greenhouse gas emissions in two alpine grassland soils under laboratory conditions. Biol Fertil Soils 49:1215-1226. https://doi.org/10.1007/s00374-013-0821-7

Cai Y, Wang X, Tian L, Zhao H, Lu X, Yan Y (2014) The impact of excretal returns from yak and Tibetan sheep dung on nitrous oxide emissions in an alpine steppe on the QinghaiTibetan plateau. Soil Biol Biochem 76:90-99. https://doi. org/10.1016/j.soilbio.2014.05.008

Chen W, Wolf B, Brüggemann N, Butterbach-Bahl K, Zheng X (2011) Annual emissions of greenhouse gases from sheepfolds in Inner Mongolia. Plant Soil 340:291-301. https://doi. org/10.1007/s11104-010-0367-5

Cornelissen JHC (1996) An experimental comparison of leaf decomposition rates in a wide range of temperate plant species and types. J Ecol 84:573-582. https://doi.org/10.2307 $/ 2261479$

Cornelissen JHC, Harguindeguy NP, Díaz S, Grime JP, Marzano B, Cabido M, Vendramini F, Cerabolini B (1999) Leaf structure and defence control litter decomposition rate across species and life forms in regional floras on two continents. New Phytol 143:191-200. https://doi.org/10.1046/j.14698137.1999.00430.x

Davidson EA, Janssens IA (2006) Temperature sensitivity of soil carbon decomposition and feedbacks to climate change. Nature 440:165-173. https://doi.org/10.1038/nature04514

Dickinson CH, Craig G (1990) Effects of water on the decomposition and release of nutrients from cow pats. New Phytol 115:139-147. https://doi.org/10.1111/j.1469-8137.1990. tb00931.x

Dickinson CH, Underhay VSH, Ross V (1981) Effect of season, soil fauna and water content on the decomposition of cattle dung pats. New Phytol 88:129-141. https://doi.org/10.1111 /j.1469-8137.1981.tb04576.x

Dong SK, Long RJ, Hu ZZ, Xu MY, Ding LM (2003) Influence of grazing intensity on performance of perennial grass mixtures in the alpine region of the Tibetan plateau. New Zeal J Agr Res 46:175-183. https://doi.org/10.1080/00288233.2003.9513545

Dong SK, Kang MY, Hu ZZ, Long RJ, Pu XP (2004) Performance of cultivated perennial grass mixtures under different grazing intensities in the alpine region of the Qinghai-Tibetan plateau. Grass Forage Sci 59:298-306. https://doi.org/10.1111 j.1365-2494.2004.00429.x

Eaten AD, Clesceri LS, Greenberg AE, Franson MAH (1992) 3500. K. D-flame photometric methods. In: Eaten AD, Clesceri LS, Greenberg AE, Franson MAH (eds) Standard methods for the examination of water and wastewater, 18th edn. American Public Health Association, Washington, District of Columbia, pp 3-80

Gillet F, Kohler F, Vandenberghe C, Buttler A (2010) Effect of dung deposition on small-scale patch structure and seasonal vegetation dynamics in mountain pastures. Agric Ecosyst Environ 135:34-41. https://doi.org/10.1016/j.agee.2009.08.006

Greenfield H, Southgate DAT (1992) Food composition data: production, management and use, Barking, UK

Gregorich EG, Janzen HH (1998) Microbially mediated processes: decomposition. In: summer M (ed) handbook of soil science. CRC Press, Boca Raton, pp 106-119

Haynes RJ, Williams PH (1993) Nutrient cycling and soil fertility in the grazed pasture ecosystem. Adv Agron 49:119-199. https://doi.org/10.1016/S0065-2113(08)60794-4

Institute of Soil Science, Chinese Academy of Sciences (ISSCAS) (1978) Physical and chemical analytical methods of soil. Shanghai Science Technology Press, Shanghai (in Chinese)

Liang DF, Niu KC, Zhang ST (2018) Interacting effects of yak dung deposition and litter quality on litter mass loss and nitrogen dynamics in Tibetan alpine grassland. Grass and Forage Sci 73:123-131. https://doi.org/10.1111/gfs.12280

Liu J, Liu J, Linderholm HW, Chen DL, Yu Q, Wu DR, Haginoya S (2012) Observation and calculation of the solar radiation on the Tibetan plateau. Energy Convers Manag 57:23-32. https://doi.org/10.1016/j.enconman.2011.12.007

Liu Y, Yan C, Matthew C, Wood B, Hou F (2017) Key sources and seasonal dynamics of greenhouse gas fluxes from yak grazing systems on the Qinghai-Tibetan plateau. Sci Rep 7: 40857. https://doi.org/10.1038/srep40857

Liu S, Zamanian K, Schleuss P, Zarebanadkouki M, Kuzyakov Y (2018) Degradation of Tibetan grasslands: consequences for carbon and nutrient cycles. Agric Ecosyst Environ 252:93104. https://doi.org/10.1016/j.agee.2017.10.011

Lu X, Yan Y, Fan J, Wang X (2015) Gross nitrification and denitrification in alpine grassland ecosystems on the Tibetan plateau. Arct Antarct Alp Res 44:188-196. https://doi.org/10.1657/1938-4246-44.2.188

Luo C, Xu G, Chao Z, Wang S, Lin X, Hu Y, Zhang Z, Duan J, Chang X, Su A, Li Y, Zhao X, Du M, Tang Y, Kimball B (2010) Effect of warming and grazing on litter mass loss and temperature sensitivity of litter and dung mass loss on the Tibetan plateau. Glob Chang Biol 16:1606-1617. https://doi. org/10.1111/j.1365-2486.2009.02026.x

Manzoni S, Jackson RB, Trofymow JA, Porporato A (2008) The global stoichiometry of litter nitrogen mineralization. Science 321:684-686. https://doi.org/10.1126/science.1159792

Murphy KL, Klopatek JM, Klopatek CC (1998) The effects of litter quality and climate on decomposition along an elevational gradient. Ecol Appl 8:1061-1071. https://doi. 
org/10.1890/1051-0761(1998)008[1061:TEOLQA]2.0. $\mathrm{CO} ; 2$

O'Hea NM, Kirwan L, Finn JA (2010) Experimental mixtures of dung fauna affect dung decomposition through complex effects of species interactions. Oikos 119:1081-1088. https://doi.org/10.1111/j.1600-0706.2009.18116.x

Olson JS (1963) Energy storage and the balance of producers and decomposers in ecological systems. Ecology 44:322-331. https://doi.org/10.2307/1932179

Semmartin M, Aguiar MR, Distel R, Moretto AS, Ghersa CM (2004) Litter quality and nutrient cycling affected by grazinginduced replacements in species composition along a precipitation gradient. Oikos 107:149-161. https://doi.org/10.1111 j.0030-1299.2004.13153.x

Semmartin M, Garibaldi LA, Chaneton EJ (2008) Grazing history effects on above-and below-ground litter decomposition and nutrient cycling in two co-occurring grasses. Plant Soil 303: 177-189. https://doi.org/10.1007/s11104-007-9497-9

Shariff AR, Biondini ME, Grygiel CE (1994) Grazing intensity effects on litter decomposition and soil nitrogen mineralization. J Range Manag 47:444-449. https://doi.org/10.2307 $/ 4002994$

Song X, Wang L, Zhao X, Liu C, Chang Q, Wang Y, Xu T, Wang D (2017) Sheep grazing and local community diversity interact to control litter decomposition of dominant species in grassland ecosystem. Soil Biol Biochem 115:364-370. https://doi.org/10.1016/j.soilbio.2017.09.003

Sun Y, Angerer JP, Hou FJ (2015) Effects of grazing systems on herbage mass and liveweight gain of Tibetan sheep in eastern Qinghai-Tibetan plateau, China. Rangel J 37:181-190. https://doi.org/10.1071/RJ14062

Sun Y, He XZ, Hou F, Wang Z, Chang S (2018) Grazing increases litter decomposition rate but decreases nitrogen release rate in an alpine meadow. Biogeosciences 15:4233-4243. https://doi.org/10.5194/bg-15-4233-2018

Tracy BF, Zhang Y (2008) Soil compaction, corn yield response, and soil nutrient pool dynamics within an integrated croplivestock system in Illinois. Crop Sci 48:1211-1218. https://doi.org/10.2135/cropsci2007.07.0390

Unuofin FO, Mnkeni PN (2014) Optimization of Eisenia fetida stocking density for the bioconversion of rock phosphate enriched cow dung-waste paper mixtures. Waste Manag 34: 2000-2006. https://doi.org/10.1016/j.wasman.2014.05.018

Vonk JA, Christianen MJA, Stapel J (2008) Redefining the trophic importance of seagrasses for fauna in tropical indo-Pacific meadows. Estuar Coast Shelf S 79:653-660. https://doi. org/10.1016/j.ecss.2008.06.002

Weeda WC (1967) The effect of cattle dung patches on pasture growth, botanical composition, and pasture utilisation. New Zeal J Agr Res 10:150-159. https://doi.org/10.1080 /00288233.1967.10423087

Yang CT, Gao P, Hou FJ, Yan T, Chang SH, Chen XJ, Wang ZF (2018) Relationship between chemical composition of native forage and nutrient digestibility by Tibetan sheep on the Qinghai-Tibetan plateau. J Anim Sci 96:1140-1149. https://doi.org/10.1093/jas/sky002

Yu XJ, Xu CL, Muhammad I, Long RJ (2013) Effects of yak dung patch dropped in cold season on soil and pasture on the Qinghai-Tibetan plateau. Acta Ecol Sin 33:241-244. https://doi.org/10.1016/j.chnaes.2013.07.001

Publisher's note Springer Nature remains neutral with regard to jurisdictional claims in published maps and institutional affiliations. 